\title{
THE OBLIGATIONS OF EXTINCT STATES
}

\author{
THOMAS BATY
}

In the transactions of the Grotius Society (Vol. IX. p. 119, London 1920) the present writer developed the thesis that there is no existing state which has succeeded to the general rights and liabilities of the defunct Austrian and Russian Empires, and that it is only puerile to consider the Austrian Republic and the Union of Soviet Socialist Republics as "Austria" and "Russia", on account of the name of the former or the size of the latter.

A state does not lose its identity because of a change of government; it does not lose its identity because of a loss of territory. But if the government functioning in a given area disappears, and is succeeded by no one government, but new governments arise and maintain themselves in various portions of the original area, then it is equally clear that the State, as such, ceases to exist, and that several new States have arisen on its ruins. Were it otherwise, Italy, as the heir of the Roman Empire, would have a good title to the continent of Europe. A state is an idea: the government which embodies it may change, but if it ceases to cohere, the idea becomes senseless, and the State ceases to exist.

The new States are no more bound by the obligations of their predecessor (further than treaties and perhaps purely local obligations may extend), than an incoming tenant is bound by the obligations of his predecessor who has been evicted, or a son by the obligations of his parent. A government's power to burden its people should not extend to bind those of them who break away from it, and found a fresh political society. The delusive analogy of private law succession on death has exercised far too persuasive an authority on many Continental European jurists in this matter. But at least it is wrong to count Rivier among their number (as Mr. Sayre does, in the learned article written by him in the American Journal of International Law for $1918^{1}$ ). For Rivier only says that the obligations of the extinguished state to private persons continue to attach to the states which have newly arisen in its place. This may be right or wrong and seems highly illogical; but the point is that Rivier quite admits that obligations of a public kind, personal to the extinct state, are extinguished. One can no more complain of this than one can complain of a debtor's dying or going bankrupt, or of a corporation's going into liquidation. The obligee has

1 Change of Sovereignty and Private Ownership of Land (1918) 12 AM. JoUn. INT. LAW, 475 , note 1. 
simply ceased to exist as a source of profit-and that is all there is to it.

I understand Dr. Berriedale Keith (State Succession) and the Italian jurists to take the same view, while Kent and Phillimore are quoted as thinking that the obligations persist. Grotius and Story, whose authority is cited by Phillimore in support of the latter opinion, only speak of the property of the suceeeding states, and are not referring at all to their obligations. Vattel says that a State's obligations by Metz become roid if it ceases to exist as an independent political society-from sny cause whatever. And besides the injustice of holding new political societies to the engagements of those very states from which they have revolted, there arises the important practical difieulty of ascertaining how the obligations are to be apportioned. By revenue $^{2}$ ? by riches? by population? by area? aroiding the special benefits derived from the original obligation?-or law? It is impossible to arrive at any just solution.

IIr. Sibley in The Story of the Manilla Ransom, which appears at p. 17 of the Journal of the Society of Comparative Legislative and International Law for February, 1925, a seholarly and able essay, states the opinion that the seheme of the Treaty of St. Germain and the Treaty of Trianon, dividing the debt of the Austrian Empire among the States (ineluding Italy and Servia) which obtained its territory, established the principle of the succession of states to the obligations of their predecessor as law. But it cannot too often be repeated that treaties are not normally made in order to secure one's rights, but to secure advantages which would not exist without them. The stipulations of a treaty are rather evidence that the object of the stipulation is not a right than evidence that it is. Mr. Sibley thinks that the group of Versailles Treaties "will presumably assert the security of the liberties of Europe longer even than the MIetz of Utrecht." Perhaps the Mietz of Utrecht did not really avail for so very long; and it may be surmised that few publicists share MIr. Sibley's cordial confidence in the Treaties of Versailles, St. Germain, Neuilly, Trianon and Lausanne. It seems to be going a good deal too far to say that because the Versailles politicans found it convenient to maintain the claims of their bond-holders on the revenues of their late allies and real or nominal enemies, the Bohemians and the Tyrolese, the Transylvanians, Italians, Servians and MIagyars, therefore a great general principle of law was established, confirming the principle that if a State disappears, the States which get its territory must pay its debts. The Allies made their friends and protegés pay; that was only natural but it was not necessarily juridical.

2 This standard was adopted by the Treaty of St. Germain. But it obviously is unduly favorable to a rich and lightly-tased territory. 
It need scarely be added that apart from the special matter of the funded debt and the secured debts of the old Empire (as to which, as Dr. Sibley pertinently points out, the matter of succession to the obligations is concluded by the Treaties), the general question of the continuance and incidence of obligations remains unaffected by what was done at the Versailles Conference. And in particular the continuance and incidence of obligations specifically affecting particular land in the territory of the exploded state, may well be decided differently from that of its other obligations. Money borrowed specifically for harbor works in Fiume might possibly have to be repaid by the state in which Fiume might some day lie. Also, the obligations of a State which splits up by agreement may well persist when those of a violently disrupted State would not; in such a case they would probably be joint and several. But it is submitted with confidence that the particular arrangements of the Versailles group of treaties are of no consequence in determining the true rule to be applied to its obligations when a state dissolves. The circumstances were too highly special; and the decision was not assumed as a matter of law but stipulated as a matter of contract. In our view-as in Rivier's, Keith's and Vattel's-the obligation of a state is the obligation of an ideal person. The obligees take the risk of the disappearance of that ideal person, as the private law obligee takes the risk of the disappearance of a real person. They have lent their credit or performed their services and supplied their goods for the purposes of a State which has vanished. Why should they call upon the people who have repudiated the whole system for reimbursement? It is surely enough, to allow a government to rivet its responsibility upon its successors in the State, without placing in its hands the power to bind revolted States! Clearly, it could not bind one revolted state, were it as big as Brazil when it broke loose from Portugal. Why then should it be able to bind five or six simultaneously revolted States?

- Mr. Sibley argues, on the basis of the general rule of Succession $^{3}$ supposed to be established by the Versailles group of Treaties, that the United States, having taken over the Philippine Islands, is liable to Great Britain for the money which Spain promised to pay to Great Britain upon the capitulation of Manilla in 1761 . He says-as is perhaps true-that there is no prescription which runs against such a claim; but he forgets that war has more than once interposed between Spain and Great Britain in the interim, and that it has been again and again declared that war puts an end to all conventional stipulations between the parties. It would be surprising if this capitulation has been

\footnotetext{
${ }^{3}$ Not only to extinct states, but to ceding states as well.
} 
restored to effect by Treaties of Peace on each occasion. MIr. Sibley thinks that the United States might have to refund on this head to Great Britain $£ 2,187,000,000$ (over $\$ 10,000,000,000$ ) as a maximum, assuming compound interest to be allowed. This is, of course, pour rire. But, putting the case on its most modest footing, it is a pretty complete reductio ad absurdum of the "succession" theory, that the United States should be called upon to pay Great Britain for ransoming Spanish Mianilla! 